\title{
Big Data Analysis as a Source of Companies' Competitive Advantage: A Review
}

\author{
Małgorzata Bartosik-Purgat, Milena Ratajczak-Mrozek
}

\section{A B S T R A C T}

Objective: The main aim of the article is two-fold: firstly, to indicate the benefits to companies. which stem from the usage of Big Data Analysis (BDA), and secondly to conceptualise main general sources of competitive advantage that BDA affords.

Research Design \& Methods: The method used in the article is a comprehensive literature review including theories of competitive advantage and relations existing on the Consumer-to-Business market including BDA.

Findings: The conducted research indicates the particular benefits as a result of using BDA, but also conceptualises and proposes three main general sources of competitive advantage that BDA affords. These include product quality, risk reduction, and a customer relationships advantage.

Implications \& Recommendations: The results have practical implications as they identify the importance and a possible application of BDA for companies from different industries. If one wants to achieve a competitive advantage, then BDA constitutes an important potential solution. However, a certain level of managerial awareness is required first in order to implement such a solution. The awareness of particular benefits which have already been achieved by competitors in the same industry by applying BDA may be an important trigger for a company to consider implementing their own BDA.

Contribution \& Value Added: The originality of the article stems from the comprehensive analysis of benefits of BDA resulting in the conceptualisation of Big Datadriven competitive advantage.

\begin{tabular}{ll}
\hline Article type: & conceptual article \\
Keywords: & Big Data Analysis; Consumer-to-Business; competitive advantage \\
JEL codes: & O32, D83
\end{tabular}

Received: 19 August 2018

Revised: 25 October 2018

Accepted: 2 November 2018

\section{Suggested citation:}

Bartosik-Purgat, M., \& Ratajczak-Mrozek, M. (2018). Big Data Analysis as a Source of Companies' Competitive Advantage: A Review. Entrepreneurial Business and Economics Review, 6(4), 197-215. https://doi.org/10.15678/EBER.2018.060411 


\section{INTRODUCTION}

Developments in technology create new business models and solutions and affect changes in existing models and business relations. This influences not only activities of companies but also of individual consumers. New technological solutions and devices, which are usually connected with the Internet, have become a background to theoretical concepts and considerations regarding markets (Manyika et al., 2011; Curry, 2016). Among these many concepts, the key ones include: the Internet of Things (IoT), Business Intelligence (BI), Customer Intelligence ( $\mathrm{Cl}$ ), Data Management (DM), and Knowledge Management (Erickson \& Rothberg, 2014; Jin, Wah, Cheng, \& Wang, 2015; He, Wang, \& Akula, 2017; Pauleen \& Wang, 2017). These concepts relate to some traditional economic theories like the Resource Based Theory or the dynamic capabilities view of the firm (Mikalef et al., 2016; Braganza et al., 2017). But most importantly, they provide advice on how to use new information and the benefits connected with its possession, especially for managers who have to make strategic, tactical, and operational decisions (Erickson \& Rothberg, 2014; Intezari \& Gressel, 2017).

The digitalisation, the Internet, and mobile activities, both of individual customers and companies, provide large amounts of unstructured data which can be analysed and used by companies for achieving better effectiveness and a competitive advantage on the market (Curry, 2016; Kaplan, 2016). A constant increase in digitalised data means that a majority of traditional ways and means of data gathering, storage and analysis are no longer well-suited to current market needs (Zikopoulos et al., 2012). Data creation in the digitalised world is now vast and continues to rise (Bumblauskas, Nold, Bumblauskas, \& Igou, 2017). According to Gartner's (2015) estimation, the amount of connected devices globally will increase to approximately 20.8 billion by 2020 . Given this, it is clear why Big Data is becoming a big deal for researchers and entrepreneurs alike. Big Data is associated with the availability of a great amount of data that originates from both internal (e.g. internal documents, e-mails and other in-company systems) and external sources (e.g. social media, GPS, etc.) and the subsequent analysis of this with the aim of achieving better results (Shanmuganathan, 2014; Wu, Zhu, Wu, \& Ding, 2014; Zhao Yeung, Huang, \& Song, 2015; Del Vecchio, Mele, Ndou, \& Secundo, 2018).

Big Data is not as yet a widely and deeply investigated field. Its appearance and usage have led to new research on the topic, but the scientific literature on these sources of information remains limited. Existing literature concentrates especially on the technical and informational aspects of Big Data usage (e.g. Bhat \& Quadri, 2015; Jin et al., 2015; Jagadish, 2015; Cheng, Zhang, \& Qin, 2016; Kim \& Cooke, 2017). There are not many studies in which companies present their methods of Big Data exploitation and the effects of that usage (exceptions include: Davenport, 2014; Srivastava \& Gopalkrishnan, 2015; Mikalef et al., 2017). But the newest publications in this area are an attempt to connect the Big Data Analysis and competitive advantage of the company (Constantinou \& Kallinikos, 2015; Mikalef et al., 2016). In addition, there are some empirical reports resulting from surveys conducted by, for example the Computing Technology Industry Association (concerning mainly the IT industry) and there is also an increasing number of articles in mainstream news outlets such as Forbes or the Economist. 
The main conclusion from the report by Teradata in cooperation with McKinsey about the usage of Big Data in companies is that Big Data constitutes one of the main challenges for companies in knowledge based economies which are aiming to gain a competitive advantage. In the report one fifth of respondents agreed with the statement that Big Data Analysis (BDA) is the main or one of the most important ways of achieving a competitive advantage on the market, and around $40 \%$ of researched managers claimed that it is one of five main determinants that influence the competitive position of a company (Big Data przynosi istotne korzyści biznesowe, 2015). As McAfee and Brynjolfsson (2012, p. 4) argue, '[BDA] may offer them even greater opportunities for competitive advantage'. Thus, although the indicated limited existing literature deals with the challenge of benefits resulting from BDA, as Wamba et al. (2015) underline 'further research is urgently needed'.

The main aim of the article is two-fold: firstly, to indicate the benefits to companies, which stem from usage of Big Data Analysis (BDA), and secondly, to conceptualise main general sources of competitive advantage that BDA affords.

To achieve this aim two detailed research questions were formulated:

RQ1: What are the benefits achieved by companies representing particular industries resulting from BDA, which in turn may constitute a source of competitive advantage? And as a result, can also small companies achieve benefits and competitive advantage from BDA or is BDA only achievable for large corporations? (practical implications)

RQ2: What are possible general sources of competitive advantage resulting from BDA? (theoretical implications)

The article consists of the following parts: first, we present materials and methods used for the research. Next, we conduct the literature review in which we present the complexity of the Consumer-to-Business (C2B) business model with special emphasis on Big Data Analysis and relate it to the theoretical background of competitive advantage. This allows us to suggest the cost-benefit analysis of BDA. The next part of the article is dedicated to the analysis of the use of Big Data in companies representing various industries. This leads us to the conceptualisation of three main general sources of advantages resulting from BDA. Finally, the article provides concluding remarks and indicates limitations, which are proposed as possible directions for future research.

\section{MATERIAL AND METHODS}

The method used in the article is a comprehensive literature review including theories of competitive advantage and relations existing on the C2B market and Big Data Analysis. We used content analysis and documents study in terms of related research problem.

The research presented in this article is essentially analytical conceptual (Wacker, 1998), as it considers and builds logical arguments about cause and effect links between the analysed variables. There is hardly any practical evidence of BDA, going beyond technical aspects of BDA, such as IT systems. Moreover, managers of companies are not willing to talk about the managerial details of BDA and its real impact on performance in terms of detailed particular effects and especially financial measures. However, analysing the BDA in a conceptual manner allows to consider benefits to companies, which stem from the usage of BDA, and to identify main general sources of competitive advantage that BDA affords. 
To link industries with particular benefits resulting from BDA and afterwards to conceptualise Big Data-driven general sources of companies' advantage, secondary sources analysis was used, including an Internet query, in which the following search phrases were applied: 'big data example', 'big data case study', 'big data in company'. The particular queries were motivated by the need to look for empirically based publications that looked specifically at real life examples of BDA used in particular industries or companies. The query was conducted both in Google search and on the Proquest, Science Direct, and Emerald databases. After an initial screening of 36 sources, only the empirically based sources illustrating real life examples were used. We understand real life examples as evidence of particular companies' benefits proved by research conducted by other researchers or by case studies presented in the industry reports. We included both peer-reviewed articles and anecdotal examples of BDA. Altogether 22 examples of BDA were used for the purpose of the article analysis. We analysed the collected examples by looking for repeating patterns and classifying them into industry type and particular categories of benefits in these industries. We applied an essay form to offer a 'state of the art', overall look at the Big Data as a result of digitalisation, the development of new technologies, and their usage in business with relation to C2B markets.

\section{LITERATURE REVIEW AND THEORY DEVELOPMENT}

\section{Big Data Analysis: Specifics and Sources}

The gathering and storage of information for analytical and commercial purposes is not a new phenomenon, neither in the literature nor in the practice of company activities (Zikopoulos et al., 2012; Davenport, 2014). To find out as much as possible about a potential customer and then prepare an offer strictly adapted to his/her needs is usually the first step for every company. This field was reserved for research market agencies, such as marketing research activities (Craig \& Douglas, 2005; Schwarzl \& Grabowska, 2015; Wątróbski et al., 2016). The term 'was' is used not without reason, because the Internet (Web 2.0 and Web 3.0) and the development of its devices influenced new opportunities for companies to gather information about their customers. It does not mean that market research is not conducted now, but it means that users' activities on the Internet give an enormous amount of valuable information about them to analysts. Those users, who are either pre-existing consumers or prospective ones, create a value which is consumed by companies or other institutional units. Such specific relations are a background for the Consumer-to-Business (C2B) model, which is rapidly taking on importance as the Internet and other technological advancements progress (Hüther, 2016; Verma, Bhattacharyya, \& Kumar, 2018). C2B model is concentrated on consumers who deliver information about their needs, preferences and behaviour. What is more, those consumers often take part in the production process, thus becoming prosumers (active consumers in the production process) (Chandler \& Chen, 2015; Hofacker, Malthouse, \& Sultan, 2016).

Apart from consumers, the $\mathrm{C} 2 \mathrm{~B}$ model concerns organisations, including production companies; services such as banks, telecommunication, touristic agencies and companies (e.g. hotels); retailers (including e-commerce) and state or other institutional units (e.g. public institutions, educational, libraries and healthcare units) (Sukumar, Natarajan, \& Ferrell, 2015; He, Wang, \& Akula, 2017; Kim \& Cooke, 2017). By using different Internet and 
mobile devices, consumers provide organisations with a great deal of information (e.g. what type of web pages they use, what kind of information they look for, what kind of products or services they are interested in, in what kind of loyalty programme they participate) (Ahsan \& Rahman, 2016). Subsequently, such information is analysed and becomes a basis for formulating business decisions. This large amount of information, known as Big Data, was defined at the beginning of twentieth century by Laney (2001), who used the concept of $3 \mathrm{~V}$, which describes the characteristics of Big Data as Volume, Velocity and Variety. These concepts refer to the features of information and the process of obtaining it. Volume is associated with the amount of information, which is almost unlimited (enormous) and gathered from diverse sources, e.g. business and individual transactions, social media, sensor data (Watson \& Marjanovic, 2013; Zhao et al., 2015; Hofacker, Malthouse, \& Sultan, 2016; He, Wang, \& Akula, 2017). What is more, the data is exchanged among devices and stored with the usage of such technologies as Hadhoop, High Performance Computing Cluster (HPCC) and Hadapt (He, Wang, \& Akula, 2017). Velocity relates to the rate at which the data is formatted and accumulated, which happens rapidly. Sensors and smart meters require the handling of enormous amounts of data in close to real time (Jacobs, 2009). In other explanations velocity is associated with the speed of data (Watson \& Marjanovic, 2013; Curry, 2016), which is especially visible 'when looking at the abundance of data that mobile devices generate about consumers and their movements' (Kaplan, 2016, p. 18). Linked to the first two, continuous data flow is also known as data streaming. Variety relates to the diversity of data and data sources, which are usually in different formats and with different level of structuring (Zikopoulos et al., 2012; Hofacker, Malthouse, \& Sultan, 2016). Some researchers also add a fourth feature of Big Data - Veracity - which refers to uncertainty and credibility of the data obtained (Normandeau, 2013; IBM, 2014). Berner, Graupner and Maedche (2014, p. 14) explain that 'Big Data is associated with increased data volume, velocity and variety but decreased data veracity'. Veracity pertains to the need to verify the data acquired. It should be borne in mind that the data placed by Internet users on different web pages or platforms is not always accurate. In turn, this can affect the accuracy of conclusions, applications and finally decisions. And if the right decisions are an effect of Big Data Analysis, then the next V - Value can also be added (Fosso Wamba et al., 2015). Value is associated with the possibility of finding a proper scenario (solutions or decisions) for achieving and increasing competitive advantage. The features of Big Data presented above, on the background of literature review, can be named as $5 \mathrm{~V}$, where Volume, Velocity, Variety, Veracity and Value are distinguished.

Big Data is also presented as the tendency of searching, retrieving, collecting and processing available data (Shanmuganathan, 2014). This is a method of the legal gathering of information from various sources and then analysing them and using them for purposes of organisations. The most important problem related to Big Data is not only collecting the information but also processing it, analysing it, and using the conclusions in practice. That is why the term which is commonly used both in the literature and among practitioners refers to the significance of analysis and is called Big Data Analysis (BDA). Bumblauskas et al. (2017, p. 706) describe BDA as a 'huge data sets requiring advanced and unique data storage, management, analysis, visualization technologies as well as statistical analysis'. Organisations (e.g. companies, banks, insurance institutions, governments and educa- 
tional units) can use Big Data Analysis according to the actions of their customers (Davenport, 2014). They have access to all customers who are Internet users or are registered in different computer systems (e.g. when they are registered as customers of a bank or a store). Curry (2016, p. 31) introduced this process as the Virtual Value Chain, where 'information flow is described as a series of steps needed to generate value and useful insights from data'. He has also introduced the idea of a Big Data Ecosystem, with different types of participants who form the market (both supply and consumer's side), for example: data suppliers, technology providers, data end users, data marketplace, start-ups and entrepreneurs, researchers and academics, regulators, standardisation bodies, investors, venture capitalists, and incubators (Curry, 2016, p. 34).

Big Data is an invaluable collection of information about consumers, their needs and behaviours that are obtained from legitimate sources (Davenport, 2014; He, Wang, \& Akula, 2017). There are many diverse sources of information that create the background of Big Data Analysis. For example, when consumers want to use a particular application by becoming a member of a variety of clubs or themed groups, when they set up accounts in various online stores, use various web portals, join loyalty programmes and, in other similar situations, they agree to their personal data being collected and processed. When consumers use different online tools, they leave 'traces' that can be used by analysts to select the proper information and prepare personalised offers for them (Davenport, 2014). For example, when a user is interested in a particular product, they search for information on Internet pages and in online stores. After some time such information (a selected offer) appears on the web pages which are currently visited by that person. Elsewhere, when individuals use online bank accounts for paying for specific goods and services (e.g. including electricity, water, and gas), the bank analyses these activities by showing them in different combinations. The analysis of data collected in Big Data sweeps allows companies to develop consumer profiles, define their needs and prepare tailored offers.

The analysis of Big Data is mainly concentrated on certain key groups of information sources. Firstly, there is streaming data, which contains data coming from Internet information systems or connected devices (He, Wang, \& Akula, 2017). These can be analysed at the same moment, i.e. in real time as they happen. Instant decisions can be made about the significance of particular information (which of them should be stored and used and which should be further analysed). Secondly, there is data delivered by internal information and customer systems of the companies or other institutions. This data delivers information about customers, such as their behaviours and decisions. Thirdly, there is social media platform data, which is especially useful for customer services, sales and marketing. Information obtained from such platforms is very difficult to analyse. The reason for this is that such data does not contain numerical values which are easier comparable. They are usually analysed in terms of the presence and content of keywords, the appearance and frequency of the social users' presence on the platforms, and their activities (e.g. the character of posts and responses to others' posts). Bain \& Company's research on Big Data usage acquired from social media shows that companies which use information obtained from social media analysis have gained an advantage over their competitors in various areas (Pearson \& Wegener, 2013). The use of social media for interacting with customers influences the development of social commerce - the usage of social media in e-commerce (Hajli, 2015). The ability to prepare a customized offer for a potential customer/social media user is possible only thanks to 
analysing Big Social Data. It delivers valuable knowledge and, if it is effectively used by a company, can increase a competitive advantage.

\section{Competitive Advantage and Benefits of Big Data Analysis}

Competitive advantage can be seen as 'being better than others'. 'Competitive advantage grows fundamentally out of value a firm is able to create for its buyers that exceeds the firm's costs of creating it' (Porter, 1985, p. 3), alternatively, competitive advantage is achieved when a company can generate more economic value than its competitors (Barney, 2011, p. 15). The wish to gain a competitive advantage leads to the continuous search for new sources of this advantage. Historically, these include two main analytical approaches: position-based, linked to the works of Porter $(1980,1985)$ and resource-based, largely associated with the work of, amongst others, Barney (1991) and Prahalad and Hamel (1990). According to the position-based approach, there are two fundamental types of competitive advantage: cost leadership and differentiation (Porter, 1985). The ability to achieve these advantages is determined by a company's business environment. According to the resource-based view, a company's competitive advantage results from unequal access to resources and their limited mobility (Barney, 1991; Prahalad \& Hamel, 1990). The main two types of competitive advantage indicated by Porter (1980) or Barney (1991) and Prahalad and Hamel (1990) may have their origin in other, more detailed sources. The following should be highlighted among others (Veliyath \& Fitzgerald, 2000; Arend, 2003; Fonfara, 2012; Sigalas, 2015; Deszczyński, 2016; Doyle \& Perez-Alaniz, 2017; Maury, 2018): the technological sources associated with $R \& D$ or product innovations; the manufacturing sources associated with the quality, the product's uniqueness and costs; marketing sources associated with market research and product adoption, the image of the company and loyalty of its customers; business relationships related to cooperation; time management - the ability to quickly response to the market changes and needs. Additionally, the digitalisation era impacts information and IT systems as sources of competitive advantage (Aguila Obra, Bruque Cámara, \& Padilla Meléndez, 2002; Javalgi, Radulovich, Pendleton, \& Scherer, 2005; O'Shannassy, 2008).The analysis of competitive advantage is inseparably linked to the problem of measuring it. Competitive advantage can only be identified by comparing one company to another. Such comparison may include general business performance or particular effects or outcomes achieved by companies (Ratajczak-Mrozek, 2017, p. 211). In the context of competitive advantage, performance can be considered from the financial perspective, for example in terms of sales and profitability (Covin \& Slevin, 1990; Havens \& Senneseth, 2001; Zahra, Ireland, \& Hitt, 2000), or from the non-financial point of view, in terms of innovation (Hagedoorn \& Cloodt, 2003; Knoben, 2008) or knowledge creation (Autio, Sapienza, \& Almeida, 2000; Covin \& Slevin, 1990; Hilmersson et al., 2015). Although the assessment of competitive advantage based on business performance is not straightforward - due to the fact that competitive advantage is not a sufficient condition for above-average performance and there is no direct causal link between them - there is no better theoretical premise than treating the creation of competitive advantage as the main way of improving a company's performance (Powell, 2001). If general business performance data is not available competitive advantage may be assessed based on benefits and costs analysis. It includes the identification of particular positive and negative effects achieved by companies which, if the positive results outweigh the negative ones, may result in a competitive advantage (Ratajczak-Mrozek, 2017, p. 211). 
The up-to-date research allows to present cost-benefit analysis of BDA, which is presented in Table 1. The data garnered by gathering the moves of Internet users from different sources are used and appreciated especially by companies that prepare personalised offers for their potential customers (Shanmuganathan, 2014; Wu et al., 2014). The data value for a particular company depends on the purpose of its usage. For example, it might use the information for reducing costs and time, preparing better product offers or making business decisions (Bumblauskas et al., 2017). The most important benefits of Big Data usage for companies are connected with cost and time savings because of the possibility to gain information about potential customers' needs very quickly and relatively cheaply (when compared to traditional marketing research procedures). Personalised offers, which are prepared for and given to customers, increase the possibility of buying (an increase in sales and gaining new customers). It has been proven that Big Data analysts are five times faster in making effective decisions than their competitors. Such companies had better financial results than their competitors who did not use BDA (Pearson \& Wegener, 2013).

From the perspective of customers and individual users, Big Data analysis allows companies to develop personalised offers which meet their individual needs (Davenport, 2014; Hofacker, Malthouse, \& Sultan, 2016). In turn, this influences the time they need to spend searching for (information about) products or services they are interested in.

Table 1. Cost-benefit analysis of BDA: Individual users and companies

\begin{tabular}{|c|c|c|}
\hline BC Analysis & Benefits & Costs \\
\hline $\begin{array}{l}\text { For customers } \\
\text { and individual } \\
\text { users }\end{array}$ & $\begin{array}{l}\text { - getting a personalised offer if they } \\
\text { use different Internet sources; } \\
\text { - saving time when searching for prod- } \\
\text { ucts or information about them. }\end{array}$ & $\begin{array}{l}\text { - too much surveillance on individual users' } \\
\text { Internet activity. }\end{array}$ \\
\hline $\begin{array}{l}\text { For } \\
\text { companies }\end{array}$ & $\begin{array}{l}\text { - provision of information about the } \\
\text { market (both individual consumers } \\
\text { and institutional units); } \\
\text { - time and cost reduction; } \\
\text { - more probability of sales increase; } \\
\text { - more probability of getting new cus- } \\
\text { tomers; } \\
\text { - better financial results. }\end{array}$ & $\begin{array}{l}\text { - complexity of data, which comes from } \\
\text { many different sources (there is a need for } \\
\text { their adaptation, segregation and conver- } \\
\text { sion into different information systems); } \\
\text { - necessity for strong control over the data } \\
\text { because of its complexity and variability; } \\
\text { - data storage; } \\
\text { - data analysis (necessity to use advanced } \\
\text { analysis tools and systems). }\end{array}$ \\
\hline
\end{tabular}

Source: own study.

Big Data usage is also connected with some limitations and costs. They are linked to the complexity and variability of data which come from diversified sources and can change very quickly (Zikopoulos et al., 2012). That is why, there is a need for constant data monitoring and control. Next, the costs for the company associated with mass data are, firstly, connected with its storage, and secondly, with the analysis (Bhat \& Quadri, 2015). The more advanced the analysis conducted, the more innovative the technology and statistical systems need to be for calculations and conclusions (Bumblauskas et al., 2017). On the other hand, for individual and average customers, Big Data is usually an unknown or incomprehensible phenomenon they are afraid of (Hofacker, Malthouse, \& Sultan, 2016). For this reason Big Data is often met with doubt and resistance from consumers, who are afraid of the excessive interference of analysts and organisations into 
their lives (Hofacker, Malthouse, \& Sultan, 2016). Therefore, in order to protect data, governments normally create legal safeguards for personal data (e.g. the General Inspectorate for Personal Data Protection in Poland).

The results of the cost-benefit analysis of BDA usage show that valuable benefits appear to be stronger when compared to the costs, both from the perspective of companies and individual customers, although each time situation and achieved benefits or incurred costs of a particular company need to be taken into consideration. The economic results of Big Data Analysis can be observed by measuring the efficiency of marketing activities of companies (e.g. personalised products and communication, adapted promotional campaigns, relation building). However, such efficiency measures are available only for particular/ interested companies and not widely published.

The newest research makes an attempt to connect the BDA and competitive advantage (Constantinou \& Kallinikos, 2015; Mikalef et al., 2016). Constantinou and Kallinikos (2015) analysed the usefulness of Big Data in the context of companies`strategy determination. They underline that Big Data is a significant source of valuable information which forms a challenge to strategy making. In the authors 'opinion, the changes in information gathering and analysing (BDA) should be constantly combined with the social and institutional context. Only such a connection provides successful management (Constantinou \& Kallinikos, 2015). In turn, Mikalef et al. (2016) proposed conceptual and theoretical research framework of using BDA as a general business potential and strategic value. Their research relies mainly on the resource-based view, IT-business and dynamic capabilities view theoretical conceptions. They suggest that companies by joining IT resources (e.g. IT Infrastructure, IT human skills \& knowledge,) and the IT enabled dynamic capabilities (e.g. learning, coordinating, integrating) with the environmental factors (like IT competences and organisational capabilities and business strategy), are able to achieve competitive performance (Mikalef et al., 2016). This theoretical model is one of the first in the literature which provides an attempt to relate companies' resources and BDA with the achievement of the competitive advantage.

\section{ANALYSIS AND DISCUSSION}

\section{The Benefits Resulting from BDA and Achieved by Particular Industries}

In order to answer the research questions, based on an analysis of secondary data presenting real life examples of BDA, in table 2 we provide examples of industries where particular benefits resulting from BDA have been identified. The identified industries are not the only examples where the BDA is used. These industries most often appeared in the publications about BDA (e.g. Constantinou \& Kallinikos, 2015) and the industry reports (e.g. Popławski, 2017).

Table 2 shows the possibilities of benefits for particular industries, resulting from BDA. Production organisations usually use data by analysing them for, on the one hand, increasing the quality of their products and efficiency and, on the other hand, for minimising losses. They also often use consumers' knowledge to prepare an offer better adapted to the market (Taylor, 2014; Hofacker, Malthouse, \& Sultan, 2016). What is more, companies use the obtained information to build relations with current and future customers. 
Table 2. Examples of industries with particular benefits resulting from BDA

\begin{tabular}{|c|c|c|}
\hline Industry & Benefits & $\begin{array}{c}\text { General sources of ad- } \\
\text { vantage }\end{array}$ \\
\hline $\begin{array}{l}\text { Production } \\
\text { companies }\end{array}$ & $\begin{array}{l}\text { - increasing the quality of their products and their effi- } \\
\text { ciency } \\
\text { - minimising losses } \\
\text { - building relations with customers }\end{array}$ & $\begin{array}{l}\text { - product quality advantage } \\
\text { - risk reduction advantage } \\
\text { - customer relationships ad- } \\
\text { vantage }\end{array}$ \\
\hline $\begin{array}{l}\text { Service - } \\
\text { banks }\end{array}$ & $\begin{array}{l}\text { - improving banking tools which are offered to customers } \\
\text { - building relationships with customers } \\
\text { - assessing the credit risk or selection of customers for } \\
\text { whom the bank will prepare a particular banking product } \\
\text { - reducing potential fraud and ensuring compliance } \\
\text { with supervisory regulations }\end{array}$ & $\begin{array}{l}\text { - product quality advantage } \\
\text { - risk reduction advantage } \\
\text { - customer relationships ad- } \\
\text { vantage }\end{array}$ \\
\hline $\begin{array}{l}\text { Service - } \\
\text { telecommu- } \\
\text { nication }\end{array}$ & $\begin{array}{l}\text { - preparing more suitable offers for customers } \\
\text { - predicting future situations and updating the strategy }\end{array}$ & $\begin{array}{l}\text { - product quality advantage } \\
\text { - risk reduction advantage }\end{array}$ \\
\hline $\begin{array}{l}\text { Service - } \\
\text { tourist in- } \\
\text { dustry }\end{array}$ & $\begin{array}{l}\text { - preparing more suitable offers for customers } \\
\text { - building relationships with customers } \\
\text { - predicting future situations and updating the strategy }\end{array}$ & $\begin{array}{l}\text { - product quality advantage } \\
\text { - risk reduction advantage } \\
\text { - customer relationships ad- } \\
\text { vantage }\end{array}$ \\
\hline $\begin{array}{l}\text { Retail - } \\
\text { traditional }\end{array}$ & $\begin{array}{l}\text { - increasing customer loyalty by personalising the offer } \\
\text { - increasing customer interest in offers and increasing } \\
\text { sales }\end{array}$ & $\begin{array}{l}\text { - product quality advantage } \\
\text { - customer relationships ad- } \\
\text { vantage }\end{array}$ \\
\hline $\begin{array}{l}\text { Retail - } \\
\text { e-commerce }\end{array}$ & $\begin{array}{l}\text { - increasing customer loyalty by personalising offers } \\
\text { - developing more efficient e-commerce activities (better } \\
\text { use of advertising budgets, purchase path optimisation) } \\
\text { - increasing customer interest in offers and increasing } \\
\text { sales }\end{array}$ & $\begin{array}{l}\text { - product quality advantage } \\
\text { - customer relationships ad- } \\
\text { vantage }\end{array}$ \\
\hline $\begin{array}{l}\text { Public } \\
\text { sector } \\
\text { institutions }\end{array}$ & $\begin{array}{l}\text { - making more effective management decisions by op- } \\
\text { timizing costs } \\
\text { - improving the quality of customer service } \\
\text { - achieving transparency } \\
\text { - greater accuracy of medical diagnosis } \\
\text { - reducing money spent on healthcare and other public } \\
\text { sector activities }\end{array}$ & $\begin{array}{l}\text { - risk reduction advantage } \\
\text { - customer relationships ad- } \\
\text { vantage }\end{array}$ \\
\hline
\end{tabular}

Source: own study.

The Big Data usage in banking institutions is connected with the constant analysis of information gathered from the market and improving banking tools which are offered to customers to make them satisfied (Srivastava \& Gopalkrishnan, 2015). In this industry BDA is used to assess the credit risk of customers, as well as provide information helpful for customer selection and preparation of offers regarding particular banking product. Banks also analyse mass information to reduce potential fraud and ensure compliance with supervisory regulations (Srivastava \& Gopalkrishnan, 2015; Saxena \& Al-Tamimi, 2017). For example, Zhao et al. (2015) prepared a model for financial units to be better prepared for the potential failure of customers. This scheme was based on external Big Data and used to increase the predictability of the potential future negative effects. In practice, banks collect data from their users' account movements (e.g. payments, their size and type of 
items purchased). Not just banks, but also other service agencies such as telecommunications or tourism companies analyse data about clients that is collected and help on their information systems and from this they attempt to prepare them the best offer. BDA also helps organisations to predict what will happen in the future (ranging from the coming weeks and months to even several years). Based on such data, telecom companies update their business strategies and actively respond to rapid changes in consumer preferences. Innovative analytical solutions help to strengthen their competitive advantage. Moreover, those companies using the BDA results and preparing special offers for potential customers are able to build closer relationships with them. Customers are able to trust and relate to companies that prepare specialised and customized offers.

The great importance of BDA is also observed in the activities of retailers (including ecommerce), where the main purpose is to generate consumer interest in an offer and subsequent sale. One such an example of using BDA for improving management is Tesco in Malaysia, which had a problem with customer loyalty (Manjur, 2014). Tesco used an analysis of market trends, data acquired from loyalty cards (e.g. what the customers were buying, when they were buying, etc.) in order to better personalise offers for particular customers. The efficiency of this BDA is clear; Tesco reactivated 3.000 of its customers and the level of loyalty increased by $30 \%$ (Ibid.). Additionally, we found that in retail sectors BDA does not just help personalise offers for customers, but also allows companies to tailor promotions or even to take advantage of local conditions in the case of nationwide retail chains (McAfee \& Brynjolfsson, 2012).

BDA also brings about many opportunities for e-commerce units. For example, Amazon developed algorithms 'to predict what books individual customers would like to read next', which in turn increased customer satisfaction and sales (McAfee \& Brynjolfsson, 2012, p. 4). In e-commerce BDA can take into account many types of information, such as: shopping volume, numbers of visits on a web page, and the data of registered customers in order to adapt special offer that fits customers' needs and preferences. Ecommerce platforms usually use multiple different sources for these same purposes, such as statistics systems (Google Analytics), advertising systems (e.g. AdWords), and Customer Relations Management systems (e.g. how many times a particular customer has contacted the company, personal data, and purchase history, etc.), mailing systems, social media profiles (e.g. current interests and 'likes'). The results of the analysis of such data can develop more efficient e-commerce activities in order to provide better results including sales increases, better price management, better use of advertising budgets, recognition of the customers preferences, adaptation of offers, and purchase path optimisation, etc. (Davenport, 2014). Big Data can be both an opportunity and a challenge to e-commerce companies as Amazon, eBay or Allegro. The usage of BDA by the companies has also an advantage from the customers ' point of view. In our opinion, personalised promotions and offers are especially useful for customers who are, firstly, active Internet users, and secondly lack time for searching for the best products.

Finally, the public sector institutions can also use BDA for improving their management, optimising costs or improving the quality of their customer services. For example, former mayor of New York, Mike Bloomberg, developed a new unit called Chief Analytics Office, whose main task is to collect and collate available data from all departments and offices. The data obtained should then be gathered and analysed in an efficient manner to 
make successful decisions. This system of Big Data analysis, introduced in New York, allows for more effective management decisions in the city in many key areas, including: traffic, security services, and emergency response. In other public sector institutions, for example the healthcare industry, it is possible to gain higher transparency and greater accuracy of medical diagnosis by digitising medical records and results of clinical research, and it also helps to reduce money spent on healthcare (Groves et al., 2013).

The analysis conducted and presented above indicates that although the benefits achieved from BDA by particular industries are interlinked and often repeat themselves, we may identify some differences. We believe that these differences result from the specificity of particular industries, as well as their daily operations and applied strategies.

Based on the presented examples, the answer to the question if also small companies may achieve benefits and competitive advantage from BDA or if BDA is only achievable for large corporations, is not straightforward. Although at least theoretically, and based on declarations from analytical companies, the application of BDA is not limited to large companies, the actual real life examples of BDA used in particular industries or companies mostly come from case studies of large companies (Rising, Kristensen, \& Tjerrild-Hansen, 2014; Mikalef et al., 2017). We believe that the reasons behind such a situation are at least twofold. First of all, conducting BDA requires a certain amount of resource investments. These include costs of systems for collecting data, servers to store large amounts of data, and systems and capabilities to analyse the data. Such systems and servers may be outsourced. However, even outsourcing requires investment, which is often considerable. Second of all, applying BDA requires a degree of managerial awareness as to BDA's ultimate profitability, which is not always the case in micro and small companies, especially those that are active in more traditional and non-digitalised industries. However, the conclusions from the industry reports concerning the BDA usage show that not only corporations and large companies will use the BDA for the achievement of their purposes (Popławski, 2017).

\section{General Sources of Competitive Advantage Resulting from BDA}

Based on the identified benefits of BDA we may conceptualise three main general sources of advantages resulting from BDA (Table 2). This conceptualisation may be linked to both position-based (Porter, 1985) and resource-based (Barney, 1991; Prahalad \& Hamel, 1990) view of competitive advantage. These identified by us Big Data-driven general sources of advantages are: product quality advantage, risk reduction advantage, and customer relationships advantage. Product quality advantage and risk reduction advantage may be seen as the most basic ones; BDA leads to more adequate and personalised products or services which, in turn, should result in sales increases. Only in the case of public sector institutions, which do not sell typical products or services (or at least do not want to be perceived as typical sellers), product quality advantage is not the main advantage achieved from BDA. Product quality advantage and risk reduction (related to some extent to cost advantage) may be linked to Porter's (1985) position-based view of competitive advantage. However, BDA does not only provide product quality and risk reduction. It can be also linked to the resource-based view and particularly to the relationships and network view on competitive advantage (which among others originates from the resource-based view (RatajczakMrozek, 2017)). It is interesting that customer relationship advantages linked to the fostering of customer loyalty and more long-term relationships with customers is more often mentioned in the case of production and retail industries, as well as public sector, but not 
service companies. This may be linked to the fact that most of the mentioned examples from service industries concern banks and financial institutions or telecommunications companies, which are usually big global companies with a large amount of power. Three Big Data-driven general sources of advantage identified by us are not exclusive but complementary. The source of competitive advantage achieved from BDA depends on the type of company and industry. The biggest benefits are identified in the companies that take into account the needs and temporary preferences of the potential customer. As our analysis of real life examples of the BDA application indicated, it is possible to benefit at the same time from all three sources of Big Data-driven advantage.

\section{CONCLUSIONS}

BDA may be perceived as an important source of competitive advantage (Big Data przynosi istotne korzyści biznesowe, 2015). Based on the conducted analysis, particular benefits arising from BDA usage were identified. Further to this, three main general sources of advantage resulting from BDA have been proposed: product quality advantage, risk reduction advantage, and customer relationships advantage. A product quality advantage means offering more adequate and suitable, often personalised, products or services to customers, which in turn leads to an increase in sales. The risk reduction advantage concerns risk reduction of both daily operations and long-termed strategic actions (such as predicting future situations and updating the strategy). Finally, the customer relationships advantage is linked to the fostering of customer loyalty and more long-term relationships with customers. All of these advantages can lead to higher profitability.

The conducted analysis has a number of managerial implications. If one wants to achieve a competitive advantage, then BDA constitutes an important potential solution. However, a certain level of managerial awareness is required first in order to implement such a solution. An awareness of particular benefits which have already been achieved by competitors in the same industry by applying BDA may be an important trigger for a company to consider implementing their own BDA. This is the case irrespective of company size. It must be remembered that sometimes managers do not include all Big Data analyses when optimising their business decisions because there is, in a sense, information overload (Power, 2002). This overloading paralyses managers' decision making and actions (Bumblauskas et al., 2017). In this situation, hiring specialists or experienced external companies providing BDA solutions may be the required form of action. We do believe that BDA and its results can and should be developed not only by corporations and big companies, but also by small and medium-sized companies in order to be more competitive on the market. Furthermore, in the digitalized era the costs of the Big Data usage is relatively low compared to the potential results achieved. What is more, smaller companies do not have to buy very expensive computer programmes for data analysis or hire many professionals for statistical analysis. They can use their strength as a possibility for fast adaptations and changes, which can result from analysis of internal data and/or market observation.

The conducted analysis is not free of limitations, although at the same time we believe that these can direct further research. One of the main research limitations is the lack of empirical research and articles showing the scope and usage of BDA. The reason for this is, firstly, a specific and technically advanced way of achieving the data, and secondly many companies are reticent about sharing their knowledge in the field of gathering data. Instead, 
companies usually underline the importance of BDA but do not disseminate their own activities. This is due to the potentially large competitive advantage which BDA usage can bring. Future research which could enhance the knowledge of BDA regarding different industries can and should include both quantitative and qualitative methods. Likewise, more finegrained results could be achieved with a focus on a particular industry, which would bring insights into competitive advantages resulting from BDA in different sectors.

\section{REFERENCES}

Aguila Obra, A.R., Bruque Cámara, S., \& Padilla Meléndez, A. (2002). Internet usage and competitive advantage: the impact of the Internet on an old economy industry in Spain. Internet Research, 12(5), 391-401. https://doi.org/10.1108/10662240210447146

Ahsan, K., \& Rahman, S. (2016). An investigation into critical service determinants of customer to business (C2B) type product returns in retail firms. International Journal of Physical Distribution \& Logistics Management, 46(6/7), 606-633. https://doi.org/10.1108/IJPDLM-09-2015-0235

Arend, R.J. (2003). Revisiting the logical and research considerations of competitive advantage. Strategic Management Journal, 24(3), 279-284. https://doi.org/10.1002/smj.285

Autio, E., Sapienza, H.J., \& Almeida, J. (2000). Effects of Age at Entry, Knowledge Intensity, and Imitability on International Growth. Academy of Management Journal, 43, 909-924. https://doi.org/10.2307/1556419

Barney, J. (2011). Gaining and Sustaining Competitive Advantage. 4th edition. London: Pearson.

Barney, J.B. (1991). Firm Resources and Sustained Competitive Advantage. Journal of Management, 17(1), 99-120. https://doi.org/10.1177/014920639101700108

Bhat, W.A., \& Quadri, S.M.K. (2015). Big Data promises value: is hardware technology taken onboard?. Industrial Management \& Data Systems, 115(9), 1577-1595. https://doi.org/10.1108/IMDS-04-2015-0160

Berner, M., Graupner, E., \& Maedche, A. (2014). The information panopticon in the Big Data era. Journal of Organisation Design, 3(1), 14-19. https://doi.org/10.7146/jod.9736

Big Data przynosi istotne korzyści biznesowe. Retrieved from https://erp-view.pl/business_intelligence/big_data_przynosi_istotne_korzysci_biznesowe.html on September 10, 2015.

Braganza, A., Brooks, L., Nepelski, D., Ali, M., \& Moro, R. (2017). Resource management in big data initiatives: processes and dynamic capabilities. Journal of Business Research, 70, 328-337. https://doi.org/10.1016/j.jbusres.2016.08.006

Bumblauskas, D., Nold, H., Bumblauskas, P., \& Igou, A. (2017). Big data analytics: transforming data to action. Business Process Management Journal, 23(3), 703-720. https://doi.org/10.1108/BPMJ-03-2016-00.6

Chandler, J., \& Chen, S. (2015). Prosumer motivations in service experiences. Journal of Service Theory and Practice, 25(2), 220-239. https://doi.org/10.1108/JSTP-09-2013-0195

Cheng, S., Zhang, Q., \& Qin, Q. (2016). Big data analytics with swarm intelligence. Industrial Management \& Data Systems, 116(4), 646-666. https://doi.org/10.1108/IMDS-06-2015-0222

Constantinou, I.D., \& Kallinikos, J. (2015). New games, new rules: big data and the changing context of strategy. Journal of Information Technology, 30(1), 44-57. https://doi.org/10.1057/jit.2014.17

Covin, J.G., \& Slevin, D.P. (1990). New venture strategic posture, structure, and performance: An industry life cycle analysis. Journal of Business Venturing, 5, 123-135. https://doi.org/10.1016/0883-9026(90)90004-D

Craig, C.S, \& Douglas, S.P. (2005). International Marketing Research. Hoboken: Wiley Publ. 
Curry, E. (2016). The Big Data Value Chain: Definitions, Concepts, and Theoretical Approaches. In J.M. Cavanillas, E. Curry \& W. Wahlster (Eds.), New Horizons for a Data-Driven Economy (pp. 2937). Springer International Publishing. https://doi.org/10.1007/978-3-319-21569-3_3

Davenport, T.H. (2014). How strategists use "big data" to support internal business decisions, discovery and production. Strategy \& Leadership, 42(4), 45-50. https://doi.org/10.1108/SL-05-2014-0034

Del Vecchio, P., Mele, G., Ndou, V., \& Secundo, G. (2018). Creating value from Social Big Data: Implications for Smart Tourism Destinations. Information Processing \& Management, 54(5), 847-860. https://doi.org/10.1016/j.ipm.2017.10.006

Deszczyński, B. (2016). The Maturity of Corporate Relationship Management. Gospodarka Narodowa, 3(283), 73-104.

Doyle, E., \& Perez-Alaniz, M. (2017). From the Concept to the Measurement of Sustainable Competitiveness: Social and Environmental Aspects. Entrepreneurial Business and Economics Review, 5(4), 35-59. https://doi.org/10.15678/EBER.2017.050402

Erickson, S., \& Rothberg H. (2014). Big Data and Knowledge Management: Establishing a Conceptual Foundation. The Electronic Journal of Knowledge Management, 12(2), 108-116.

Fonfara, K. (Ed.). (2012). The Development of Business Networks in the Company Internationalisation Process. Poznań University of Economics Press.

Fosso Wamba, S., Akter, S., Edwards, A., Chopin, G., \& Gnanzou, D. (2015). How 'Big Data' can make big impact: findings from a systematic review and a longitudinal case study. International Journal of Production Economics, 165, 234-246.

Gartner (2015). Gartner says 6.4 billion connected 'things' will be in use in 2016, up 30 percent from 2015. Retrieved from www.gartner.com/newsroom/id/3165317 on September 20, 2018.

Groves, P., Kayyali, B., Knott, D., \& Van Kuiken, S. (2013). The 'big data' revolution in healthcare: Accelerating value and innovation. McKinsey \& Company.

Hagedoorn, J., \& Cloodt, M. (2003). Measuring innovative performance: is there an advantage in using multiple indicators?. Research Policy, 32(8), 1365-1379. https://doi.org/10.1016/S0048-7333(02)00137-3

Hajli, N. (2015). Social commerce constructs and consumer's intention to buy. International Journal of Information Management, 35(2), 183-191. https://doi.org/10.1016/j.ijinfomgt.2014.12.005

Havens, P.-A., \& Senneseth, K. (2001). A Panel Study of Firm Growth among SMEs in Networks. Small Business Economics, 16, 293-302. https://doi.org/10.1023/A:1011100510643

He, W., Wang, F-K., \& Akula, V. (2017). Managing extracted knowledge from big social media data for business decision making. Journal of Knowledge Management, 21(2), 275-294. https://doi.org/10.1108/JKM-07-2015-0296

Hilmersson, M., Johanson, M., Lundberg, H., Papaioannou, S., \& Thyr, A. (2015). Business networks, firm strategy, opportunity development and strategic outcomes: a conceptualization of the initial phase of firm internationalization. In J. Larimo, N. Nummela, \& T. Mainela (Eds.), Handbook on International Alliance and Network Research (pp. 171-194). Cheltenham: Edward Elgar.

Hofacker, Ch.F., Malthouse, E.C., \& Sultan, F. (2016). Big Data and consumer behavior: imminent opportunities. Journal of Consumer Marketing, 33(2), 89-97. https://doi.org/10.1108/JCM-04-2015-1399.

Hüther, M. (2016). Digitalisation: An engine for structural change - A challenge for economic policy. IW Policy Paper, Institut der deutschen Wirtschaft Köln, 15 . Retrieved from ttps://www.iwkoeln.de/_storage/asset/317422/storage/master/file/11350973/download/IW_policy_paper_2016_15_Digitalisation.pdf on September 20, 2018.

IBM (2014). The Four V's of Big Data, IBM. Retrieved from ww.ibmbigdatahub.com/infographic/fourvs-big-data on September 16, 2018. 
Intezari, A., \& Gressel, S. (2017). Information and reformation in KM systems: big data and strategic decision-making. Journal of Knowledge Management, 21(1), 71-91. https://doi.org/10.1108/JKM-07-2015-0293

Jacobs, A. (2009). The pathologies of big data. Communications of the ACM, 52, 36-44. https://doi.org/10.1145/1536616.1536632

Jagadish, H.V. (2015). Big Data and Science: Myths and Reality. Big Data Research, 2(2), 49-52. https://doi.org/10.1016/j.bdr.2015.01.005

Javalgi, R.G., Radulovich, L.P., Pendleton, G., \& Scherer, R.F. (2005). Sustainable competitive advantage of internet firms: A strategic framework and implications for global marketers. International Marketing Review, 22(6), 658-672. https://doi.org/10.1108/02651330510630276

Jin, X., Wah, B.W., Cheng, X., \& Wang, Y. (2015). Significance and Challenges of Big Data Research. Big Data Research, 2(2), 59-64. https://doi.org/10.1016/j.bdr.2015.01.006

Kaplan, A.M. (2016). O Brave New World that has such creatures in: how digital media shape corporations, organizations and society at large. In G. Mazurek \& J. Tkaczyk (Eds.) The Impact of the Digital World on Management and Marketing (pp. 17-22). Warsaw: Kozminski University Publ.

Kim, Y-S., \& Cooke, L. (2017). Big data analysis of public library operations and services by using the Chernoff face method. Journal of Documentation, 73(3), 466-480. https://doi.org/10.1108/JD08-2016-0098

Knoben, J. (2008). Firm Mobility and Organizational Networks. Innovation, Embeddedness and Economic Geography. Cheltenham: Edward Elgar.

Laney, D. (2001). 3D data management: Controlling data volume, velocity, and variety. Technical report, META Group.

Manjur, R. (2014). Case Study: How Tesco brought loyalty back to its stores. Retrieved from http://www.marketing-interactive.com/case-study-tesco-brought-loyalty-back-stores/ on September 20, 2014.

Manyika, J., Chui, M., Brown, B., Bughin, J., Dobbs, R., Roxburgh, C., \& Byers, A.H. (2011). Big data: The next frontier for innovation, competition, and productivity. McKinsey Global Institute.

Maury, B. (2018). Sustainable competitive advantage and profitability persistence: Sources versus outcomes for assessing advantage. Journal of Business Research, 84, 100-113. https://doi.org/10.1016/j.jbusres.2017.10.051

Mikalef, P., Framnes, V.A., Danielsen, F., Krogstie, J., \& Olsen, D. (2017). Big Data Analytics Capability: Antecedents and Business Value. PACIS 2017 Proceedings. 136.

Mikalef, P., Pappas, O.I., Giannakos, N.M., Krogstie, J., \& Lekakos, G. (2016). Big Data and Strategy: a Research Framework. Conference: Tenth Mediterranean Conference on Information Systems (MCIS), Cyprus.

Normandeau, K. (2013). Beyond Volume, Variety and Velocity is the Issue of Big Data Veracity. Retrieved from https://insidebigdata.com/2013/09/12/beyond-volume-variety-velocity-issuebig-data-veracity/on September 12, 2013.

O'Shannassy, T. (2008). Sustainable competitive advantage or temporary competitive advantage: improving understanding of an important strategy construct. Journal of Strategy and Management, 1(2), 168-180. https://doi.org/10.1108/17554250810926357

Pearson, T., \& Wegener, R. (2013). Big data: the organizational challenge. Retrieved from www.bain.com/publications/articles/big_data_the_organizational_challenge.aspx on October 22, 2018. 
Pauleen, D.J., \& Wang, W.Y.C. (2017). Does big data mean big knowledge? KM perspectives on big data and analytics. Journal of Knowledge Management, 21(1), 1-6. https://doi.org/10.1108/JKM-08-2016-0339

Popławski, K. (2017). 5 branż, które wydadzą najwięcej na Big Data, CRN. Retrieved from https://www.crn.pl/aktualnosci/5-branz-ktore-wydadza-najwiecej-na-big-data on March 21, 2017.

Porter, M.E. (1980). Competitive Strategy. New York: Free Press.

Porter, M.E. (1985). Competitive Advantage. Glenwood: Free Press.

Powell, T.C. (2001). Competitive advantage: Logical and philosophical considerations. Strategic Management Journal, 22(9), 875-888. https://doi.org/10.1002/smj.173

Power, D. (2002). Decision Support Systems: Concepts and Resources for Manager. Cedar Falls, IA.

Prahalad, C.K., \& Hamel, G. (1990). The Core Competence of the Corporation. Harvard Business Review, 79-91. Retrieved from http://scholar.google.com/ scholar?hl=en\&btnG=Search\&q=intitle:Copyright+(C2001.+All+Rights+Reserved.\#0on September 20, 2018.

Ratajczak-Mrozek, M. (2017). Network Embeddedness. Examining the Effect on Business Performance and Internationalization. Cham: Palgrave Macmillan. https://doi.org/10.1007/978-3-319-56511-8

Rising, C.J., Kristensen, M., \& Tjerrild-Hansen, S. (2014, Summer). Is Big Data too Big for SMEs? Leading Trends in Information Technology. Stanford University.

Saxena, S., \& Al-Tamimi, T.A.S.M. (2017). Big data and Internet of Things (IoT) technologies in Omani banks: a case study. Foresight, 19(4), 409-420. https://doi.org/10.1108/FS-03-2017-0010

Shanmuganathan, S. (2014). From data mining and knowledge discovery to big data analytics and knowledge extraction for applications in science. Journal of Computer Science, 10, 12, 2658-2665.

Sigalas, Ch. (2015). Competitive advantage: the known unknown concept. Management Decision, 53(9), 2004-2016. https://doi.org/10.1108/MD-05-2015-0185

Srivastava, U., \& Gopalkrishnan, S. (2015). Impact of big data analytics on banking sector: Learning for Indian banks. Procedia Computer Science, 50, 643-652. https://doi.org/10.1016/j.procs.2015.04.098

Sukumar, S.R., Natarajan, R., \& Ferrell, R.K. (2015). Quality of Big Data in health care. International Journal of Health Care Quality Assurance, 28(6), 621-634. https://doi.org/10.1108/IJHCQA-07-2014-0080

Schwarzl, S., Grabowska, M., (2015). Online marketing strategies: the future is here. Journal of International Studies, 8(2),187-196. https://doi.org/10.14254/2071-8330.2015/8-2/16

Taylor, A.R. (2014). Postmodernist and consumerist influences on information consumption. Kybernetes, 43(6), 924-934. https://doi.org/10.1108/K-07-2013-0127

Veliyath, R., \& Fitzgerald, E. (2000). Firm capabilities, business strategies, customer preferences, and hypercompetitive arenas: the sustainability of competitive advantages with implications for firm competitiveness. Competitiveness Review: An International Business Journal, 10(1), 56-82. https://doi.org/10.1108/eb046389

Verma, S., Bhattacharyya, S.S., \& Kumar, S. (2018). An extension of the technology acceptance model in the big data analytics system implementation environment. Information Processing \& Management, 54(5), 791-806. https://doi.org/10.1016/j.ipm.2018.01.004

Wacker, J.G. (1998). A definition of theory: research guidelines for different theory-building research methods in operations management. Journal of Operations Management, 16, 361-385. https://doi.org/10.1016/S0272-6963(98)00019-9

Wątróbski, J., Jankowski, J., \& Ziemba, P. (2016). Multistage Performance Modelling in Digital Marketing Management. Economics and Sociology, 9(2), 101-125. https://doi.org/10.14254/2071789X.2016/9-2/7 
Watson, H.J., \& Marjanovic, O. (2013). Big data: the fourth data management generation. Business Intelligence Journal, 18(3), 4-8.

Wu, X., Zhu, X., Wu, G.Q., \& Ding, W. (2014). Data mining with big data. IEEE Transactions on Knowledge and Data Engineering, 26(1), 97-107. https://doi.org/10.1109/TKDE.2013.109

Zahra, S.A., Ireland, R.D., \& Hitt, M.A. (2000). International Expansion by New Venture Firms: International Diversity, Mode of Market Entry, Technological Learning, and Performance. The Academy of Management Journal, 43, 925-950. https://doi.org/10.2307/1556420

Zhao, X., Yeung, K., Huang, Q., \& Song, X. (2015). Improving the predictability of business failure of supply chain finance clients by using external big dataset. Industrial Management \& Data Systems, 115(9), 1683-1703. https://doi.org/10.1108/IMDS-04-2015-0161

Zikopoulos, P., Parasuraman, K., Deutsch, T., Giles, J., \& Corrigan, D. (2012). Harness the Power of Big Data The IBM Big Data Platform. NY: McGraw Hill Professional. 


\section{Authors}

The contribution share of authors is equal and amounted to $50 \%$ each of them.

\section{Małgorzata Bartosik-Purgat}

Associate Professor in the Department of International Management at the Poznan University of Economics and Business. Her research addresses: cultural aspects in international business, consumer behaviour, consumer ethnocentrism, and significance of social media in culturally diversified marketplace.

Correspondence to: Prof. UEP dr hab. Małgorzata Bartosik-Purgat, Poznan University of Economics and Business, Faculty of International Business and Economics, al. Niepodległości 10, 61312 Poznań, Poland, e-mail: malgorzata.bartosik-purgat@ue.poznan.pl

\section{Milena Ratajczak-Mrozek}

Associate Professor in the Department of International Marketing at the Poznan University of Economics and Business. Her main areas of research include the analysis of company relationships and cooperation in an international setting as well as competitive advantage in the global market. She focuses on the analysis of both SMEs and large multinationals from the high technology and furniture industries.

Correspondence to: Dr hab. Milena Ratajczak-Mrozek, Poznan University of Economics and Business, Faculty of International Business and Economics, al. Niepodległości 10, 61312 Poznań, Poland, e-mail: milena.ratajczak-mrozek@ue.poznan.pl

\section{Acknowledgements and Financial Disclosure}

Scientific grant no. 2015/17/B/HS4/00309 of National Science Centre, Poland.

\section{Copyright and License}

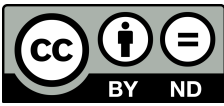

This article is published under the terms of the Creative Commons

Attribution - NoDerivs (CC BY-ND 4.0) License http://creativecommons.org/licenses/by-nd/4.0/

\section{Published by the Centre for Strategic and International Entrepreneurship - Krakow, Poland}


